\title{
Spinoza's exchange with Albert Burgh
}

\author{
Edwin Curley
}

In September 1675 Albert Burgh, a young man who had been a close friend and admirer of Spinoza, sent him a long and passionate letter, imploring him to convert, as Burgh himself had recently done, to the Catholic faith. Spinoza was initially reluctant to reply, but when he did so, his response was generally temperate, concise, and tinged with sadness at his friend's conversion. In this chapter I propose to examine this correspondence, to see what it can tell us about the reception of the Tractatus Theologico-Politicus, and about Spinoza's philosophy as it appears in that work.

I've characterized Burgh's letter to Spinoza as passionate. It is also highly abusive. Although Burgh starts by saying how much he had previously admired Spinoza's acute and subtle intelligence, and by granting that Spinoza loves, and is even eager for, the truth, he quickly passes to saying that his friend has let himself be led astray by the Devil, the Prince of Wicked Spirits, and that his philosophy is a complete delusion. ${ }^{I}$ Spinoza is "a wretched little man, a base little earthworm, indeed, ashes, food for worms." Rash, insanely arrogant, puffed up with diabolic pride, Spinoza blasphemes by believing himself to be superior to Jesus.

This may not seem a very promising way to try to convert a friend to your new religion. Nevertheless, at the end of his letter Burgh insists that he has written it

I Ep. 67; $G$ IV 28I.

2 I presented an earlier version of this essay to the Southeastern Seminar in Early Modern Philosophy, in Tampa, in November 2007. I'm indebted to the participants in the discussion for their comments, and especially indebted to Yitzhak Melamed, whose comments on the penultimate version of this chapter encouraged significant improvements in its argument. I am also indebted to the School of Historical Studies at the Institute for Advanced Study in Princeton, for the membership during which I completed the revision of this essay.

All translations from the TTP and the Letters are mine, from the current draft of my translations for Vol. II of the Collected Works of Spinoza, forthcoming from Princeton. When published, my translations will have the Gebhardt pagination in the margins. So in my references here I make use of the Gebhardt volume and page numbers. The passage quoted here comes from Vol. IV, p. 283. For citations of the TTP I also give chapter and Bruder paragraph numbers, which will be included in my edition. 
with a truly Christian intention: first, that you may know the love I have for you, even though you are a Pagan; and second, that I might call upon you not to persist in corrupting others too... God wants to snatch your soul from eternal damnation, provided you are willing. Do not hesitate to obey the Lord, who has called you so often through others, and now calls you again, perhaps for the last time, through me, who, having attained this grace by the inexpressible mercy of God himself, pray wholeheartedly that you will attain the same grace. ${ }^{3}$

The Lord may work in mysterious ways, but in this case his instrument was not very effective. Spinoza did not convert to Christianity, much less to Catholic Christianity. In fact, Burgh's letter provoked Spinoza to be more openly critical of organized religion than he had been in the TTP itself, demonstrating that aggressive proselytization can backfire. At the end of his reply Spinoza characterizes Roman Catholic Christianity as a "pernicious superstition." 4 Though some of his grounds for that condemnation may be specific to the Roman Church, others would apply equally well to many other Christian denominations. Or so I shall argue. Spinoza also characterizes rabbinic Judaism and Islam as forms of superstition. Examining this correspondence should help us to clarify Spinoza's concept of superstition, suggest a theory about what might make a religion merit that label in Spinoza's eyes, and help to explain why Spinoza might nevertheless encourage state support of religions he regarded as superstitious.

So much for prologue. Recently Jonathan Israel has devoted several pages of his magisterial Radical Enlightenment to the correspondence between Burgh and Spinoza, in a chapter entitled "Miracles Denied." I agree with Israel that Spinoza's denial of miracles was a major issue between him and Burgh, that this denial distressed many of Spinoza's readers, and that the questioning of miracles was a major theme in the Enlightenment to come. Still, Israel presents Spinoza as more innovative than he actually was. Hobbes, as Israel is aware, had also written quite skeptically about miracles, arguing that men were apt to give much too hasty credence to miracle stories. Hobbes's official position does concede that sometimes miracles really happen. Israel emphasizes that fact to characterize Hobbes as less radical than Spinoza on this issue. But I think Hobbes's concession is ironic, and that he essentially agrees with Spinoza in rejecting miracles. When Hobbes read Spinoza's TTP, he is reported to have said: "He has

$3 G$ IV 29I.

$4 G$ IV 323a. The $a$ here refers to the fact that of the two versions of Spinoza's reply in the Gebhardt edition, I cite the one in the upper half of the page, which appeared in Spinoza's Opera Posthuma. The version which Gebhardt reproduces in the lower half of the page is a copy made by Leibniz.

5 See Israel, Radical Enlightenment, pp. 218-229. 
outthrown me a bar's length; I durst not write so boldly." ${ }^{6}$ The rejection of miracles is one way in which Spinoza is bolder - in spite of his motto, less cautious in his criticism of traditional religion. ${ }^{7}$

But I think we miss the most central disagreement between Burgh and Spinoza if we focus too exclusively on the issue of miracles. What Burgh is most concerned about is to convince Spinoza that

the Catholic Teaching is the wisest, and admirable in its profundity - in a word, that it surpasses all the other Teachings in the world... [it] teaches [men] the secure path to peace of mind in this life, and delivers the eternal salvation of the soul to be achieved after this. ${ }^{8}$

Spinoza not only rejects Burgh's claim for the Catholic Church, but does so in terms which imply a rejection of all forms of organized Christianity.

Burgh argues that the Christian religion is founded on historical facts, which "tens of thousands" of people accept, many thousands of whom "far

6 This remark is often misquoted, because the standard edition of its source, Aubrey's life of Hobbes in his Brief Lives, misreads the ms. at this point. Clark reads: "He has cut through me a bar's length...," which doesn't make much sense. Some Hobbes scholars have made the obscurity of the remark on that reading a ground for doubting that Hobbes ever said it. (See Hood, Divine Politics, and Pinto's emendation of the text, proposed in the TLS in September 1950.) Pinto explains that the reference is to a trial of strength in which players compete to see how far they can throw a bar.

I've compared Hobbes's position on miracles with Spinoza's in Curley, "Durst." There I argue also: (I) that if we compare the TTP with Leviathan, on several topics which they both discuss in the theological portions of their works - specifically, prophecy, miracles, and the authority of Scripture we shall find much in Spinoza's work which Hobbes might have found to be bolder than what he had written on the same topics; (2) that where Spinoza's position is bolder, Hobbes's less radical position is often stated in a way suggesting irony; (3) that since irony often functions as a way of hinting at views it would be dangerous to express openly, Hobbes's use of it is evidence that he would have gone further than he did, if he thought he could have done so safely; (4) that it is entirely credible that Hobbes said what Aubrey says he said; and finally, (5) that Hobbes is properly viewed (with Spinoza) as a precursor of such Enlightenment figures as Voltaire and Hume. In spite of the surface deference he often shows to orthodox Christian doctrines, he is essentially a secular thinker, whose religious views are subversive of those held by most Europeans of his time. (This article, originally published in Bostrenghi's Hobbes \& Spinoza, is available on my website: http://sitemaker.umich. edu/emcurley/hobbes.)

Since writing the article cited above, I have published an edition of Leviathan which notes the variations between the English edition of I65I and Hobbes's Latin version, published in 1668 in the Netherlands. This was one of two editions of Leviathan Spinoza would have had available to him when he was writing the TTP (the other being a Dutch translation, published in 1667). On the interest in Hobbes in the Netherlands see Secretan, "La reception de Hobbes," in the special issue of Studia Spinozana devoted to Spinoza and Hobbes, Vol. 3, 1987.

7 However, even Spinoza finds it prudent to veil his rejection of miracles in the ordinary sense of the term by allowing that we can define the term in a way which permits us to affirm that miracles occur: we can understand by a miracle, not an event contrary to the laws of nature, but "a work whose natural cause we cannot explain by the example of another customary thing, or at least which cannot be so explained by the one who writes or relates the miracle." See TTP Ch. 6, ๆฯ 6-I5; G III 82-84. When miracles are equated with human ignorance in this way, they become far too common to provide a grounding for religious claims.

${ }^{8}$ G IV 289. 
surpassed, and surpass, [Spinoza] in learning, in refinement, in true, precise solidity, and in perfection of life." 9 Among the things this argument from consensus is supposed to prove are the facts that

Christ, the Son incarnate of the living God, suffered, was crucified, and died for the sins of the human race, that he was resurrected, transfigured, and reigns in the heavens, God with the eternal Father, in unity with the Holy Spirit, and the rest of the things which belong to this, the countless miracles which have been done in God's Church by the same Lord Jesus, and afterward, in his name, by the Apostles and the rest of the Saints. ${ }^{\mathrm{IO}}$

Miracles play an evidentiary role here, in so far as the miracles performed by Jesus and his followers attest to the truth of the religion he founded. But they are themselves events whose actual occurrence Burgh acknowledges must be proven. He does this by arguing that many, many people believe they really occurred, and that among these many, many people are many whose learning and moral character are excellent.

On Burgh's view, this consensus of the learned and virtuous is itself direct evidence for some of the historical facts which constitute the foundation of Christianity, facts not in themselves miraculous, such as the facts that Jesus suffered and was crucified. If we denied that events so widely accepted really happened, we would have no ground for accepting such secular events as Julius Caesar's transformation of the Roman Republic into a monarchy. Our belief in the undoubted occurrences of secular history rests on no better ground than the consensus of many thousands of people. A consistent skepticism about the historical claims of the Christian religion would have to be skeptical about all of secular history as well. "It is impossible that everyone who asserts such things ... would either have deceived themselves, or have wanted to deceive others through the succession of so many ages." II

In advancing this argument from consensus Burgh displays a deep skepticism about the evidence of the senses:

You can never be confident about whether the human mind possesses the ideas of all created things naturally, or whether external objects or the suggestion of good or evil spirits produce many, if not all, of them. ${ }^{22}$

Without consulting the testimonies of other men, how would Spinoza be able to tell whether there are, or can be, in nature, such things as divining rods, the alchemist's stone, the magic of incantations, sirens, gnomes, and any number of other supernatural phenomena? Burgh clearly believes in such things, and sees testimony as providing legitimate support for his
9 G IV 285 .
I0 $G$ IV 285 .
II $G$ IV 286.
I2 $G$ IV 284 . 
beliefs. He does not seem to have paused to reflect that he needs to have some trust in the evidence of his senses in order to know that other men are testifying to the facts he takes their testimony as evidence for. Although it's certainly true that we do rely on testimony for justifying much of what we believe, testimony is hardly an independent source of knowledge, which can provide the justification for our reliance on the senses.

When Spinoza replies to Burgh, he does not address Burgh's skeptical arguments for reliance on testimony, except in so far as they seem to rely on the possibility of deception by a demon:

you lament that I allow myself to be led astray by the Prince of wicked Spirits. But I beg you to be of good heart, and return to yourself. When you were in possession of your faculties, unless I'm mistaken, you worshiped an infinite God, by whose power absolutely all things happen and are preserved. But now you are dreaming of a Prince, an enemy of God, who, contrary to the will of God, leads astray and deceives most men - good men, in fact, are rare - and that for that reason God hands these men over to this master of wicked acts, to be tortured to eternity. The divine justice therefore allows the Devil to deceive men with impunity. But the men the Devil has wretchedly deceived and led astray are by no means without punishment. ${ }^{\mathrm{I3}}$

So the idea of deception by the Devil, which Burgh had used both to explain Spinoza's embrace of heresies and also as a general ground for skepticism about the senses, Spinoza rejects as incompatible with the idea of God as an infinite being. If God's power is infinite, the Devil cannot deceive men without God's permission. If God's justice is infinite, he would not punish men for being deceived by a Devil who was acting with God's permission.

Burgh's first argument, then, for the proposition that the teaching of the Catholic Church surpasses all other teachings, is simply that thousands upon thousands of people, many of whom are exemplary in their learning and virtue, believe this to be true. So far miracles are a part of the story, but a relatively small part of it. They are among the things which the consensus among the faithful warrants us in believing. And they are among the things which warrant other beliefs the faithful hold. But Burgh has several other arguments, none of which involves miracles.

Some of them seem to be arguments not so much for the superiority of Catholic teaching as for the superiority of Christianity in general, by comparison with other religions. His second argument, for example, invites Spinoza to reflect on the fact that

I3 $G$ IV 319a. 
from the beginning of the world to this day God's Church has been spread without interruption, and continues unchanged and solid, whereas all other religions, whether pagan or heretical, have at least had a later beginning, if they have not also already come to an end. ${ }^{14}$

There's a certain tension in this line of argument, of course. To make the Christian religion older than any other he has to treat it as having begun at the creation, that is, to treat Judaism as simply the first stage of the Christian religion. But this seems incompatible with his claim that the Christian religion has continued unchanged from the beginning of the world, since the work Christians call the "New Testament" is socalled because it introduces a new conception of the covenantal relationship between God and his people.

Burgh's third argument asks Spinoza to consider that the fact that Christianity spread because "unlearned men" were nevertheless able to convert most of the pagan world by teaching a doctrine which is "contrary to common sense, and exceeds and transcends all human reasoning." Is In spreading the good news they "received no aid from the power of kings and earthly princes," who in fact persecuted them vigorously.

Consider that in this way Christ's Church spread throughout the world in a short period of time, and that finally, the Roman Emperor himself having been converted to the Christian faith, along with the kings and princes of Europe, the Church hierarchy increased its power to such an extent that it can be wondered at today. Consider that all this was brought about through love, gentleness, patience, trust in God, and all the other Christian virtues ... ${ }^{16}$

I4 $G$ IV 286-287. I5 $G$ IV 287 .

I6 $G$ IV 287. Burgh is by no means original in making this argument. A version of it appears in Aquinas's Summa contra gentiles, I, vi, 3, where Thomas argues for the reasonableness of Christian belief on the ground that "This wonderful conversion of the world to the Christian faith is the clearest witness of the signs given in the past; so that it is not necessary that they should be further repeated, since they appear most clearly in the effect. For it would be more wonderful than all signs if the world had been led by simple and humble men to believe such lofty truths, to accomplish such difficult actions, and to have such high hopes. Yet it is also a fact that, even in our own time, God does not cease to work miracles through His saints for the confirmation of the faith." Pegis edn., I, pp. 72-73. In the following section Thomas discounts the success of Islam by arguing that "those who believed in [Mohammed] were brutal men and desert wanderers, utterly ignorant of all divine teaching, through whose numbers Mohammed forced others to become his followers by the violence of his arms."

In the seventeenth century Bayle gave this argument a special twist in his Commentary, when he argued against a common interpretation of the parable of the great dinner in Luke I4, that a literal interpretation of the parable, often used to justify forced conversion, would deprive Christianity of its principal claim to superiority over Islam (Book I, Ch. vii). Whether Christianity is entitled to claim that it spread only by peaceful means, whereas Islam was largely spread by force, is doubtful, as the text will shortly make clear. I presume Bayle knew this. He certainly knew that in his own day Louis XIV was using force against the Huguenots, trying to make France wholly Catholic. 
Of all of Burgh's arguments, this is the only one Spinoza will give any weight to. He does not directly challenge it, but contents himself with pointing out that "this argument supports not the Roman Church, but everyone who professes the name of Christ." "17

Still, Spinoza shows he is unhappy even with this argument. For him it is no recommendation of the Christian religion that it requires belief in things which are contrary to common sense (sensui communi repugnat) and teaches things which "exceed human reasoning." The particular example he cites involves the Catholic doctrine of the Eucharist:

O, young man bereft of understanding, who has bewitched you, so that you believe you are eating that highest and eternal being ${ }^{18}$ and have him in your intestines? ${ }^{19}$... Stop calling absurd errors mysteries... and do not shamefully confuse things which are unknown to us, or not yet discovered, with those which are demonstrated to be absurd, as are the horrible secrets of this Church. The more [these secrets/mysteries] are contrary to right reason, the more you believe they transcend the intellect. ${ }^{20}$

If unlearned men have been able to persuade thousands upon thousands of people to accept such absurdities, the proper conclusion to draw is, not that the absurdities are true, but that in the wretched despair which the uncertainty of human affairs produces, people can be made to believe almost anything which offers a way out of their difficulties. So Spinoza had argued in the opening paragraphs of the Preface to the TTP, in his discussion of the psychological basis for superstition.

Spinoza does not directly question the factual claims Burgh makes about the rapid rise of Christianity. But those claims are dubious, and unless we suppose that Spinoza was as ignorant as his correspondent, we must assume that he knew this. Christianity did, of course, spread rapidly in the first few centuries after the death of Jesus. At the beginning of the fourth century

He himself had fled France to escape persecution. When he used the comparative freedom of the Netherlands to publish a critique of a Catholic history of Calvinism, his brother, who had remained in France, was put in prison, where he soon died.

Arguably, Islam has historically been more tolerant of religious minorities than Christianity has. See Cohen, Crescent and Cross. In his recent (and generally sympathetic) history of Christianity, Diarmaid MacCulloch claims that "For most of its existence, Christianity has been the most intolerant of world faiths, doing its best to eliminate all competitors, with Judaism a qualified exception, for which (thanks to some thoughts of Augustine of Hippo) it found space to serve its own theological and social purposes." MacCulloch, Christianity, p. 4.

$17 G$ IV 322a. I8 $G$ IV 319a.

19 I learn from Professor Lasker's contribution to this volume that this was a common theme in Jewish polemics against Christianity. I learn from Hoffmann's "Anatomy" that it was also a common theme in Protestant polemics against Catholic Christianity.

${ }^{20} G$ IV 323a. 
Christians seem to have still constituted a relatively small percentage of the population of the Empire as a whole: probably somewhere between 7 and Io percent. ${ }^{2 I}$ Considering how few followers Jesus must have had at the time of his death, that's impressive growth. Still, the transition from being a small (but significant) minority religion to being the majority religion occurred in the fourth century, when the emperors were predominantly Christians, who used their political power to advance the cause of their religion. ${ }^{22}$ Between the accession of Constantine in 312 and the end of Theodosius's reign in 395, the number of Christians in the Empire seems to have grown from around 5 million to around 30 million. ${ }^{23}$ But during that period, contrary to what Burgh assumes, those spreading the faith received considerable "aid from the power of kings and earthly princes."

The first Christian emperor, Constantine, did not persecute pagans in the way his predecessor, Diocletian, had persecuted Christians. He preferred the carrot to the stick. One of his first acts, after he rose to power in the western Empire, was to persuade his colleague in the east, Licinius, to join him in promulgating the Edict of Milan, which granted "both to Christians and to all men freedom to follow whatever religion one wished." ${ }^{24}$ This commitment to religious liberty did not, however, mean that he would not favor his own religion. He did much to give Christianity a privileged position among Roman religions: first, by engaging in what Drake has described as "a massive redistribution of patronage resources to the bishops," 25 but also, as Barnes notes, by giving "freely from the imperial treasury, both to build or enlarge churches, and to decorate them richly," stripping the pagan temples of their treasures, exempting the Christian clergy from taxation, and changing the laws regarding marriage and divorce, to bring them in line with Christian values. ${ }^{26}$

2I I take this estimate from Drake, Constantine, p. 495 n. 2. It seems to be a consensus view. Though their numbers may have been small, Christians evidently exercised an influence out of proportion to their numbers. Cf. Barnes, Constantine, p. I9I.

22 The exception, of course, was Julian, called "the Apostate," who tried, during his brief reign (November 36I-June 363), to restore paganism to what he thought its rightful place was.

23 This is MacMullen's estimate, in Christianizing, p. 86. Stark, Rise, suggested that Christianity may have become the majority religion as early as the middle of the fourth century. He arrives at an estimated 56.5 percent of the population in $350 \mathrm{CE}$ by assuming a base of 1,000 Christians in the year $40 \mathrm{CE}$, a growth rate of 40 percent per decade up till 350 , and a population of the Empire in 350 of 60 million. He stresses that for over a century the Mormons have achieved a growth rate of this magnitude. He acknowledges that his starting figure of $\mathrm{I}, \mathrm{OOO}$ Christians in $4 \mathrm{O} \mathrm{CE}$ is somewhat arbitrary, but seems safe in his assumption that the number of Christians at that point must have been very small. More dubious, as he acknowledges, is his assumption of a constant rate of growth. If we suppose that the rate of growth may, at some periods, have been less than 40 percent, Christianity would not have achieved majority status quite so quickly.

24 Drake, Constantine, p. I94. $\quad{ }_{25}$ The quote is from Drake, "Constantine," p. 39I.

26 Barnes, Constantine, pp. 48-54, 246-247. 
Though Constantine thought a Christian emperor should not persecute pagans, he did not hesitate to persecute Christians who dissented from the decisions of church councils. By using the power of the state to enforce orthodox belief among Christians, Drake has argued, he "erode[d] the long-held Christian principle that belief could not be coerced," 27 thereby paving the way for his successors to persecute pagans. By the end of the fourth century the emperor was using his power vigorously, not only to favor Nicene Christianity in its competition with the Arian and Donatist heresies, but also to repress paganism:

Theodosius caused surviving pagan sacrifices at Alexandria and Rome to cease and proscribed domestic cults (I6.IO.IO-II). The world-renowned Temple of Serapis at Alexandria was destroyed by monks led on by the local bishop, while Roman officials stood by. Riots by the Christian mobs, fueled by the promise of spoils, spread like wildfire. ${ }^{28}$

Contrary to what Burgh claims, not everything was done through love, gentleness, patience, and the other Christian virtues. I would not suggest that the support Christianity received from the state was anything like the sole cause for the dramatic increase in the numbers of Christians during the fourth century. To explain a phenomenon of this magnitude we would have to invoke many causes, as Gibbon did in Chapter $\mathrm{xv}$ of his classic Decline and Fall of the Roman Empire. ${ }^{29}$ But it's hard to believe that it did not have some effect.

Spinoza does not have the advantage of modern scholarly knowledge of the ancient world. So he would not have been in a good position to make even the rough estimates of Christian numbers I have made in the last few paragraphs. The most he could have said with any justification would have been: Christians must have constituted a tiny minority of the population of the Empire during most of the first century; by the beginning of the fourth century, they were probably a significant minority, though still distinctly a minority; by the end of the fourth century, they were probably a majority. But he certainly would have been in a position to know that in its latter stages this growth did not occur without significant support from Constantine and his successors. That much he could have learned from Eusebius's Life of Constantine or Ammianus Marcellinus. That the subsequent spread of Christianity beyond the Roman Empire owed much to the sword, he would also have known from the history of the Jews and

\footnotetext{
27 Drake, Constantine, p. 439.

28 King, "Theodosius." For a more detailed account, see King, Establishment.

29 To Gibbon's five causes we might now wish to add others, suggested by Stark, Rise.
} 
Muslims in Iberia, and of Protestant Christians and indigenous peoples in the lands ruled by Spain in the sixteenth century. ${ }^{30}$

What Spinoza challenges, though, in his reply to Burgh is his contention that the Catholic Church is unique in its claim to antiquity, immutability, and perpetuity:

What you add about the common agreement of many thousands of men, and about the uninterrupted succession of the Church, etc., is the same old song of the Pharisees. For with no less confidence than those devoted to the Roman Church, they display many thousands of witnesses, who report the things they have heard as things they have experienced ... they trace their lineage all the way to Adam, and boast with equal arrogance that their Church has spread to this day, and remains unchanged and genuine, in spite of the hostility of the Pagans and the hatred of the Christians ... What they are most proud of is that they count far more martyrs than any other nation, and that the number of those who have suffered for the faith they profess increases daily. ${ }^{31}$

Spinoza then tells the story of a certain Judah, called the faithful, a Christian noble in Spain who had converted to Judaism, and who died at the stake, singing a hymn to God in the midst of the flames. Though Burgh would prefer to ignore it, Christians have been both the persecuted and the persecutors. Their unfortunate belief that there is no salvation outside the Church, a belief Burgh explicitly endorses, gives them a perverse incentive to bring people to the faith, and keep them there, by whatever means they find necessary.

Nowadays we call the view that salvation awaits all and only those who accept a certain religion exclusivism. ${ }^{32}$ Burgh is an exclusivist in that sense, and is arguing for the acceptance of a brand of Christianity which has long been exclusivist. The Second Vatican Council may have changed that. It would be pleasant to think so. But it remains to be seen how deep and lasting that council's distancing of Catholicism from exclusivism will be. Before he became pope, Benedict XVI seemed to be bent on returning the Church to its historical position on the relation between Catholic

30 The best treatment of this I know is Fletcher, Barbarian Conversion. $\quad$ 3I $G$ IV 32Ia-322a.

32 Or "soteriological exclusivism," as Quinn and Meeker call it, in the introduction to Quinn and Meeker, Challenge. Exclusivists are prone to find support for their position in such passages as John 3:I6, I8: "For God so loved the world that he gave his only Son, so that everyone who believes in him may not perish, but may have eternal life... Those who believe in him are not condemned; but those who do not believe are condemned already, because they have not believed in the name of the only Son of God." Some authors use "exclusivism" in a different sense, to apply to religions which hold that there is only one God, and that worship of any other god is therefore inappropriate. Cf. Drake, Constantine, pp. 479-480. On this view monotheism is inherently exclusivist. 
Christianity and other faiths. ${ }^{33}$ Now conservatives in the Church appear to have the upper hand.

Exclusivism is often criticized as being arrogant. We can see one ground for that criticism in Burgh's arguments for the superior wisdom of Catholic teaching. One of the claims he makes for his faith is that Catholics are just better than other people from a moral point of view.

Countless Catholics of each sex ... have lived wonderful and most holy lives ... the most perfect Heretic or Philosopher who ever lived hardly deserves to be considered among the most imperfect Catholics. ${ }^{34}$

So it's not just that on average Catholics are morally superior to nonCatholics. Even the worst of Catholics is superior to even the best of non-Catholics.

In our more ecumenical times, when we are prone to acknowledge the existence of moral virtue in people of many different faiths, and even, occasionally, in the non-religious, this affirmation of the moral superiority of Catholic Christians may make Burgh seem both ridiculous and irrelevant. But there is a certain logic in his position. If religion is the foundation of morality, and if there is but one true religion, then it seems reasonable to suppose that the true religion ought to be more effective than other religions in making its adherents morally virtuous. If there is only one religion which can truly offer salvation, then it seems that if God is just, the adherents of that one salvific religion ought to be more deserving of an eternal reward than those outside the salvific religion. So we might expect an exclusivist to embrace the following set of propositions:

(I) There is exactly one true religion, acceptance of which is necessary and sufficient for salvation.

(2) God is just.

(3) The adherents of the one true religion are uniformly morally superior to the adherents of all other religions, and to those who have no religion. The first of these propositions defines exclusivism, as I am here understanding that term. I take "acceptance of a religion" here to include at least

33 See "Dominus Iesus," a Declaration by the Congregation for the Doctrine of the Faith, issued when the present Benedict XVI was still Cardinal Ratzinger, and Prefect of the Congregation. According to this document, those outside of Christianity are "in a gravely deficient situation" in comparison with Christians and non-Catholic Christians have "defects" in comparison with Catholic Christians. A Church which claims infallibility for the decrees of popes and ecumenical councils cannot easily admit that its previous teaching was wrong.

34 IV 289 . 
acceptance of its central teachings about God and its central moral teachings. The second proposition is widely accepted in monotheistic religions. ${ }^{35}$ The third proposition looks like it ought to follow from the first two. The assumption here would be that in a world governed by a just God, if salvation is granted to all and only those who adhere to a particular religion, then the adherents of that religion must be uniformly morally superior to the adherents of other religions.

Some might object that this assumption ignores a fundamental Christian teaching: that all men are sinners, and indeed, sufficiently sinful that what they deserve is damnation. Paraphrasing Hamlet, we might say: "Use every man after his desert and who should scape [not just whipping, but] hell?" This seems to be the teaching of Paul:

There is no distinction, since all have sinned and fallen short of the glory of God, they are now justified by his grace as a gift, through the redemption that is in Christ Jesus ... (Romans 3:22-24)

On this view if Christians and only Christians are saved, that is not because of their superior virtue, but because of their faith, which is "reckoned" to them as righteousness (Romans 3:28, 4:3). The fact that only Christians will be saved is no reason to expect them to be better than other people.

That may be a more authentic interpretation of Christianity than Burgh's. But it is not his interpretation of Christianity. And his particular combination of views seems to open exclusivism up to empirical refutation. The simple fact is that there is no religion whose adherents have a monopoly on moral virtue. Spinoza makes this point effectively when he replies to Burgh. First, he points out, as politely as possible, that the leaders of the Catholic Church have not always been paragons of virtue:

I shall not, as the opponents of the Roman Church usually do, relate the vices of the Priests and Popes, to turn you away from them. For these stories are often brought up maliciously, more to irritate than to instruct. ${ }^{36}$

Spinoza is reluctant to belabor the sins of the Church's leaders. He makes his point clearly enough without engaging in a catalog of papal sins. But he prefers to emphasize the positive, by granting that

in the Roman Church there are more men of great erudition, who have led commendable lives, than in any other Christian Church.

\footnotetext{
35 The scriptural traditions of the three major monotheistic religions make this a difficult proposition to deny. Negative theologians like Maimonides may find it too anthropomorphic. But negative theologians tend to get in trouble with their co-religionists.

36 IV 3I7a.
} 
But this, he says, is because this church has more adherents than any other. So inevitably "there are more men of every condition in it." The crucial point, for Spinoza, is that

in every Church there are many very honorable men, who worship God with justice and loving-kindness. For we know many men of this kind among the Lutherans, the Reformed, the Mennonites, and the Enthusiasts, ${ }^{37}$ and, not to mention others, your own ancestors, who in the time of the Duke of Alva, suffered all kinds of torture for the sake of religion, with equal constancy and freedom of mind..$^{38}$

The Duke of Alva was a general whom Philip II sent to govern the Spanish Netherlands in the sixteenth century, who acquired the nickname "the Iron Duke" because of the brutality he used in suppressing the Protestant revolt. This is a gentle reminder that the Church did not sustain its position solely by the practice of Christian virtues.

Earlier I proposed what we might call the exclusivist syllogism and suggested that Burgh accepts all three propositions, while Spinoza rejects the third at least.

(I) There is exactly one true religion, acceptance of which is necessary and sufficient for salvation.

(2) God is just.

(3) The adherents of the one true religion are uniformly morally superior to the adherents of all other religions, and to those who have no religion. If the third proposition does in fact follow from the first two, this raises the question which of the first two Spinoza would reject.

I think he would reject both of them. Although I've described the second proposition as an assumption widely accepted in monotheistic religions, I think Spinoza would regard it as too anthropomorphic to be accepted in its most natural interpretation. God is not like a king or prince proportioning rewards and punishment to merit and demerit. ${ }^{39}$ But he would also reject the first proposition. There is not one true religion, acceptance of which is both necessary and sufficient for salvation. There are many paths to salvation. In that sense Spinoza is a pluralist.

Now some may object that, however much we in the twenty-first century might wish it were otherwise, Spinoza is no pluralist. ${ }^{40}$ If this is not clear in the TTP, it becomes quite clear in the Political Treatise, where he

\footnotetext{
37 A term generally applied in the seventeenth century to those Christians who believed themselves to be immediately inspired by God. Cf. Locke, Essay, Bk. Iv, Ch. I9.

${ }^{38} G$ iv 317a-318a.

39 Cf. Ethics E2p3s with TTP Ch. 4, 930 ; $G$ III 64, where Spinoza explicitly rejects the attribution of justice (and compassion) to God.

40 This is, essentially, an objection Yitzhak Melamed raised against an earlier version of this chapter.
} 
prescribes that in an aristocracy it is essential for the rulers to agree in endorsing and practicing one national religion. ${ }^{41}$ Other religions are to be allowed, but only subject to certain restrictions. They may build as many houses of worship as they wish, but these must be kept "small, modest, and somewhat dispersed," whereas the temples devoted to the national religion should be "large and magnificent." The rights Spinoza explicitly grants the civil authorities in the TP are implicit in the position he takes in the TTP, Chapter 19, where he insists that it is the prerogative of the civil authorities to determine in what way people are obliged to obey God and practice the externals of religious worship. ${ }^{42}$

All this is true, of course. But when we are considering Spinoza's advocacy of a national religion, whose practice is to be regulated by the sovereign, we must keep in mind his insistence that this national religion be the "universal religion" he described in Chapter I4 of the TTP. ${ }^{43}$ That universal religion is clearly meant to represent what Spinoza takes to be the common core of the monotheistic religions which take their origin in the Jewish and Christian Scriptures. He equates its tenets with

the fundamental principles of the whole of Scripture, all of which ... must tend to this point: that there is a supreme being, who loves Justice and Loving-kindness, whom everyone, if he is to be saved, is bound to obey and to worship by practicing Justice and Loving-kindness toward his neighbor. ${ }^{44}$

Spinoza goes on to enumerate seven doctrines which he claims follow from this foundation:

(i) that God exists, in the sense that there is a supremely just and merciful supreme being; (ii) that this supreme being is uniquely an appropriate object of devotion, admiration, and love; (iii) that he is present everywhere, and that everything is known to him; (iv) that he has the supreme right and dominion over all things, and does nothing because he is compelled by a law, but acts only from his absolute good pleasure and special grace; (v) that the proper worship of and obedience to this being consist only in justice and loving-kindness, or in the love of one's neighbor; (vi) that all and only those who obey God by living in this way are saved, the rest, who live under the control of the pleasures, being lost; and finally, (vii) that God pardons the sins of those who repent. ${ }^{45}$

4I TP Ch. 8, art. 46; $G$ III 345 .

42 See particularly TTP Ch. I9, ๆ $124-27 ; G$ III 232-233, but also Ch. 19, ๆ 3; $G$ III 229, for Spinoza's insistence that the sovereign's power extends only to the external practice of religion.

43 Spinoza makes this clear in TP Ch. 8, art. 46. He describes the tenets of the universal religion in TTP Ch. I4, ๆ $24-34 ; G$ III I77-I79.

44 TTP Ch. I4, ๆ 24; $G$ III 177.

45 Here I paraphrase (closely) and abridge, rather than quote fully, Bruder 9 /25-28; G III I77-I78. 
There are two things in particular which need to be noticed here. First, there is nothing specifically Christian about this universal religion, much less specifically Protestant or Catholic. In abridging this passage I did omit its only reference to Christ. But all Spinoza says when he does mention Christ - in his gloss on the proposition that God pardons the sins of those who repent - is that

whoever firmly believes that God, out of mercy and the grace by which he directs everything, pardons men's sins, and who for this reason is more inspired by the love of God, that person really knows Christ according to the Spirit, and Christ is in him. ${ }^{46}$

So if you believe in God's mercy, and if that belief inspires you to love God all the more, then you have the spirit of Christ in you, whatever you may believe about the historical Jesus of Nazareth, whether you think he was the son of God, or the Messiah, or a supremely wise moral teacher, or for that matter, merely an unusually charismatic preacher, who had some important moral insights, but may have erred in many ways (who did err, one might think, if he claimed to be the Messiah, or the son of God). You may have the spirit of Christ in you even if you have never heard of Jesus. So far as I can see, there is nothing in this which any Christian or any Jew need object to. Nor, I think, does this universal religion contain anything a Muslim would necessarily find objectionable.

The second point we need to notice is that though this "universal faith" is clearly intended to articulate a kind of lowest common denominator of the major monotheistic religions, it is couched in terms which Spinoza himself could not literally accept, and which no one who has accepted the teaching of the TTP prior to Chapter I4 could literally accept. It uses language Spinoza has previously devoted much space to rejecting as involving an inadequate, anthropomorphic conception of God. It is anthropomorphism to think of God as just, or merciful, or as a lawgiver to whom obedience is due. Spinoza makes provision for those who might agree with him in rejecting scriptural anthropomorphism when he adds, immediately after his enumeration of the tenets of this faith, that it does not matter how people interpret them, so long as they interpret them in a way consistent with the practice of justice and loving-kindness:

As for the rest - what God, or that model of true life, is, whether he is fire, spirit, light, thought, etc. - that does not matter as far as faith is concerned; nor does it matter in what way he is a model of true life, whether because he

${ }^{46}$ TTP Ch. I4, I 28; $G$ III 178. 
has a just and merciful heart or because all things exist and act through him, and hence that we also understand through him, and see, through him, what is true, right, and good. It is all the same, whatever anyone maintains about these matters.

Again, it does not matter, as far as faith is concerned, whether someone believes that God is everywhere according to his essence or according to his power, or that he directs things from freedom or from a necessity of nature, or that he prescribes laws as a prince or teaches them as eternal truths, or that man obeys God from freedom of the will or from the necessity of the divine decree, or finally, that the reward of the good and punishment of the evil is natural or supernatural.

It does not matter, I say, as far as faith is concerned, how each person understands these and similar things, provided he does not conclude that he should take a greater license to sin, or that he should become less obedient to God. ${ }^{47}$

So Spinoza explicitly permits an interpretation of these tenets which would be consistent with his own philosophy. What matters for him, in the end, is simply conduct: whether a person is committed to loving God, however he may conceive of God, practicing justice, and loving his fellow man. This is very much in the spirit of modern pluralism, as advocated, for example, by John Hick.

But Spinoza is a pluralist with a difference. Unlike modern pluralists, he thinks that some of the religions in which we can be saved are forms of superstition. This is clear in the case of Roman Catholicism, which he explicitly characterizes as a "pernicious" superstition, even though he grants that there are many men who have lived commendable lives within that religion. How is this possible?

The answer, I think, lies in Spinoza's distinction between the theoretical aspect of religion and its practical aspect. Catholic Christianity involves theoretical beliefs, some of which are absurd, such as the belief that in the Eucharist the worshiper is literally eating the body of his God. That is sufficient to qualify Catholicism as a superstition. Perhaps there is no great harm in that particular belief. But Catholic Christianity also involves beliefs which can be very harmful, such as the belief that salvation is possible only within the Church, which provides an incentive to persecute non-believers, if not to convert them to belief, then at least to prevent them from corrupting the faithful. ${ }^{8}$ That is sufficient to qualify Catholicism as a pernicious superstition. But within the Catholic Church there may be people who do not accept all the doctrines the Church hierarchy thinks they ought to accept, men like Rousseau's Savoyard vicar, who does not

47 TTP Ch. I4, ๆ『 30-32; G III 178.

$4^{8}$ As, for example, in Aquinas, Summa theologiae, II-II, Qu. Io, art. 8. 
care at all about theological niceties, and who is motivated by his belief in a personal, loving and just God to practice justice and loving-kindness himself, and to encourage the spread of those virtues. The beliefs of such a Catholic might still be superstitious, because of the anthropomorphism they involve. But they would not be pernicious. They would, in fact, be very beneficial, not only to the person so motivated, but also to the society in which he lives. That is one reason, I think, why Spinoza argues that the state may, and should, sponsor a suitably purified universal faith.

At the beginning of the chapter I suggested that Spinoza might characterize many of the Christian denominations of his day as forms of superstition. What might he think were legitimate grounds for that characterization? If the argument of this chapter is correct, it seems likely that Spinoza would reject as superstitious any religion which claimed that salvation was possible only within that religion. Exclusivism is a form of superstition. So is the advocacy of mysteries. The example most prominent in the letter to Burgh is the Catholic doctrine of the Eucharist. But any doctrine which a church proclaims as being beyond the power of human reason to understand seems a likely candidate. So the doctrine of the dual nature of Christ, that Jesus was both fully human and fully divine, would be another example. There were hints of this in the TTP itself, and the correspondence with Oldenburg confirms it. ${ }^{49}$ Another example would be the Christian doctrine of hell, fear of which Spinoza calls "the sole cause of superstition." 50

On his own principles, Spinoza exaggerates in saying this. The Preface to the TTP suggests a psychological account of superstition which relates it to more general causes in human nature than the fear of hell. Spinoza opens that Preface by writing that:

If men could manage all their affairs by a definite plan, or if fortune were always favorable to them, no one would be gripped by superstition. But often they are in such a tight spot that they cannot decide on any plan. Then they usually vacillate wretchedly between hope and fear, desiring immoderately the uncertain goods of fortune, and ready to believe anything whatever. ${ }^{51}$

The examples Spinoza goes on to give in that context involve pagans, who thought they could learn the future from reading the entrails of animals,

49 So, for example, in TTP Ch. I, - 24; $G$ III 2I Spinoza writes that he does not deny "the things certain churches maintain about Christ"; he simply does not understand them. In Ep. 73 he is more forthcoming: "As for what certain churches add to this [sc. that God's wisdom was manifested most through Jesus Christ] - that God assumed a human nature - I warned expressly that I don't know what they mean. Indeed, to confess the truth, they seem to me to speak no less absurdly than if someone were to say to me that a circle has assumed the nature of a square" ( $G$ IV 309a).

50 $G$ IV 323. $\quad$ 5I $G$ III 5 . 
and to some extent even control the future by getting the gods on their side. So he permits his Christian readers to suppose that only pagan beliefs are in question when he talks of superstition. One thing which is clear from the letter to Burgh is that this is not true, that much of the organized religion of his day is in question. What makes these religions forms of superstition is the illusion they cultivate that the world is governed by a supernatural being - or beings - who can and will intervene in its history to reward those they favor and punish those they dislike. That is common ground between paganism and Christianity.

The Preface to the TTP also suggests a further reason why Spinoza may have thought it desirable for the state to sponsor a religion he regarded as superstitious. It's not just that with suitable purification superstition can motivate us to do good. The causes of superstition lie deep in human nature. Even the most knowledgeable and powerful among us have very limited knowledge and power. We are all at the mercy of fortune, vulnerable to external causes which may help preserve us if we are lucky, or destroy us if we are not. Not knowing our fate, we cannot help but vacillate between hoping for the best and fearing the worst. It is natural for us to want to believe in the existence of powers who may protect us from what we fear, if only we can win their favor. Superstition is too deeply rooted in the human condition to be eradicated. But with good management it can be made less harmful, more beneficial. That is what Spinoza's universal religion seeks to achieve. 